\title{
Memahami Etika Pendidik dan Peserta Didik (Telaah Pemikiran KH. Hasyim Asy'ari dalam Kitab Adab al-'Alim wa al-Muta'allim )
}

\author{
Hepi Ikmal \\ Universitas Islam Lamongan \\ Email:akmaldebayor@gmail.com
}

Article History:

Received: $12-02-2020$

Revised : 15-03-2020

Accepted: 09-03-2020

\begin{abstract}
Appreciation for the works written by Muslim thinkers in the archipelago is still considerably apprehensive. In fact, there have been many productive Indonesian ulema (Muslim scholars) inheriting the treasury of scholarship. For that reason, the writer tries to study the thinking of KH Hasyim Asy'ari, more specifically about the ethics of educators and learners that he described in the Adab al-'Alim wa al-Muta'allim. The results showed that learners should be able to apply knowledge in accordance with the unity of so-called amaliah (deeds) that uphold the noble moral values integrally. This understanding is be based on his very sharp emphasis on the ethical field of learners. KH. Hasyim Asy'ari requires learners to be obedient and subject to the advice and instruction of their educators. The most obvious portrait of the dynamics of education that applies this view can be seen from some salafi pesantren (Islamic boarding schools) in Indonesia. On the one hand, this view is less reflective of providing opportunities and appreciation to learners, but on the other hand, this view reflects the KH Hasyim Asy'ari's consistent lines of thought genuinely glorifying scholars. Educators as people who have the scientific capacity should be prioritized than the learners.
\end{abstract}

Keywords: educators, learners, Islamic education

\section{Pendahuluan}

Islam sebagai ajaran, sesungguhnya merefleksikan nilai-nilai pendidikan yang mampu membimbing dan mengarahkan manusia, sehingga menjadi manusia yang sempurna. Islam sebagai agama universal telah memberikan pedoman hidup bagi manusia menuju kehidupan bahagia, yang pencapaiannya bergantung pada pendidikan. Pendidikan merupakan kunci penting untuk membuka jalan kehidupan manusia. Islam sangat berhungungan erat dengan pendidikan. Hubungan antara keduanya bersifat organis-fungsional; pendidikan berfungsi sebagai alat untuk mencapai tujuan Islam, ${ }^{1}$ dan Islam menjadi kerangka dasar pengembangan pendidikan Islam, serta memberikan sistem nilai untuk mengembangkan berbagai pemikiran tentang pendidikan Islam.

Pendidikan dianggap wahana tepat membangun masa depan umat. Berbagai petunjuk Alquran maupun Sunnah menyangkut pendidikan umumnya menunjukkan bahwa tujuan utama pendidikan adalah moralitas (akhlak) dan pengembangan

\footnotetext{
${ }^{1}$ Hery Noer Ali, Ilmu Pendidikan Islam (Jakarta: Logos Wacana Ilmu, 1999), 2
} 
kecakapan (keahlian). ${ }^{2}$ Di samping tujuan tersebut, pendidikan Islam ditujukan untuk membina manusia agar mampu menjalankan fungsinya sebagai hamba Allah dan khalifah-Nya. Manusia yang dibina adalah makhluk yang memiliki unsur-unsur material (jasmani) dan imaterial (akal dan jiwa). Pembinaan akalnya menghasilkan ilmu, pembinaan jiwanya mengahasilkan kesuciaan dan etika, sedangkan pembinaan jasmaninya menghasilkan keterampilan. ${ }^{3}$

Namun, melihat kenyataan potret pendidikan di Indonesia dewasa ini, sungguh amat memprihatinkan. Karena dalam prakteknya penekanan pendidikan yang muncul lebih berorientasi pada pencerdasan intelektual (aql) semata dan mengabaikan pembinaan etika, keyakinan (hati), kesadaran akal budi dan dimensi spritual terhadap Tuhan. maka tak bisa dipungkiri, produk pendidikan Indonesia banyak menghasilkan intelektual yang tak memiliki nurani dan tanggung jawab moralitas yang tinggi.

Jika sistem Barat sekarang ini disebut-sebut mengalami krisis yang akut, itu tak lain karena proses yang terjadi dalam pendidikan tak lain dari pada sekedar pengajaran. Pendidikan yang berlangsung dalam suatu schooling system tak lebih dari suatu transfer ilmu dan keahlian dalam kerangka tekno-struktur yang ada. Akibatnya, pendidikan menjadi komoditi belaka dengan berbagai implikasinya terhadap kehidupan sosial kemasyarakatan. ${ }^{4}$

Untuk itu, berkembang pemikiran tentang pentingnya mengubah paradigma pendidikan, karena pendidikan yang ada sekarang dipandang belum mampu mengantarkan peserta didik menjadi manusia yang sesungguhnya. Pendidikan yang seyogyanya diartikulasikan sebagai upaya memanusiakan manusia, justru mengarah pada dehumanisasi: manusia seperti kehilangan arah dan tujuan hidup serta semakin teralienasi dari hakikat kemanusiaannya. ${ }^{5}$ Karena pendidikan hanya dimaknai tidak lebih sebagai transmisi pengetahuan an sich, maka peserta didik gagal menerapkan pengetahuannya ditingkatan praksis kehidupan nyata.

Begitu juga pada masa modern, tidak sedikit intelektual muslim yang mampu menghadirkan karya-karya besarnya di bidang pendidikan. Diantaranya adalah Hadratus Syaikh KH. Hasyim Asyari dengan karyanya Adab al-'Alim wa al-Muta'allim. Sungguhpun demikian, pemanfaatan terhadap kajian teoritisasi pendidikan Islam yang dilakukan oleh generasi muslim akhir sangat minim. Kalangan intelektual agaknya kurang memberi perhatian secara serius terhadap kekayaan Islam itu.

Di tengah krisis yang melanda dunia pendidikan Indonesia tidak meletakkan dimensi moral-spritual dalam skala prioritas pendidikan, sehingga makin menambah panjang daftar krisis multidimensi di Indonesia akhir-akhir ini, maka tentu saja konsep pendidikan Islam yang ditawarkan oleh KH. Hasyim Asy’ari kiranya layak diapresiasi dan perlu dikaji.

2Said Agil Huzain Al-Munawwar, Aktualisasi Nilai-Nilai Qur'ani Dalam Sistem Pendidikan Islam (Ciputat: PT. Ciputat Press, 2005), 48

${ }^{3}$ Abuddin Nata, Filsafat Pendidikan Islam (Jakarta: Logos Wacana Ilmu, 2001), 52

${ }^{4}$ Azyumardi Azra, Pendidikan Islam, Tradisi dan Modernisasi Menuju Millenium Baru (Jakarta: Logos Wacana Ilmu, 2000), 3-4

5 Tedi Priatna, Reaktualisasi Pendidikan Islam (Bandung: Pustaka Bani Quraisy, 2004), vii 


\section{Etika Pendidikan Islam dalam Pembelajaran}

Pendidikan Islam memfokuskan terhadap perubahan tingkah laku manusia yang konotasinya pada pendidikan etika. Di samping itu, pendidikan Islam juga menekankan aspek produktifitas dan kreatifitas manusia sehingga mereka bisa berperan serta berprofesi dalam kehidupan masyarakat. Dalam konteks ini, etika pendidikan Islam dan pembelajaran merupakan dua hal pokok yang penting untuk dikemukakan, karena keduaduanya ibarat mata rantai yang saling terkait satu sama lain. Hasan Langgulung berpendapat bahwa : "pertama sekali karena pendidikan lebih umum dari proses pembelajaran, begitu juga belajar lebih luas dari penghayatan. Dengan kata lain pendidikan mengandung proses pembelajaran, sedang nilai-nilai Islam-yang terkait dengan etika- adalah kandungan dari penghayatan itu." ${ }^{A}$ rtinya, pendidikan Islam yang dimanifestasikan dalam proses pembelajaran secara instrinsik mesti terkandung penghayatan nilai-nilai Islam, seperti etika.

KH. Hasyim Asy'ari sesungguhnya telah menawarkan suatu konsep etika pendidikan Islam dalam pembelajaran yang masih relevan dan layak untuk diaktualisasikan sampai sekarang. Menurutnya, secara garis besar, dalam pembelajaran seyogyanya diperhatikan dua hal tentang etika pendidikan :pertama, seorang peserta didik yang menuntut ilmu hendaknya berniat murni untuk menuntut ilmu dengan niat suci dan luhur, jangan sampai memiliki niat untuk memperoleh kepentingan yang berorientasi pada duniawi. Kedua, seorang pendidik atau ulama dalam mengajarkan ilmunya, hendaknya meluruskan niatnya dulu, tidak mengharapkan materi semata-mata. Dan semua yang diajarkan hendaknya sesuai dengan tindakan dan perilaku yang diperbuat, dalam arti bukan sekedar hanya bisa menyampaikan belaka. ${ }^{7}$

Di samping KH. Hasyim Asy'ari, sebenarnya terdapat tokoh-tokoh pendidikan Islam yang lain, seperti al-Ghazali dan al-Zarnuji yang menawarkan konsep tentang etika pendidikan Islam dalam pembelajaran. Namun konsep yang ditawarkan kedua tokoh tersebut memiliki sisi kesamaan paradigmatik dengan model (konsep) KH. Hasyim Asy'ari.

\section{Kandungan Kitab Adab al-'Alim wa al-Muta'allim}

Secara global, kitab Adab al-'Alim wa al-Muta'allim membicarakan tiga hal pokok, yaitu: prinsip dasar pendidikan, tanggung jawab dan tugas peserta didik, dan tanggung jawab dan tugas pendidik. Tiga hal pokok tersebut dijabarkan kedalam delapan bab. Kedelapan bab itu meliputi penjelasan tentang: keutamaan ilmu dan ilmuwan serta keutamaan pembelajaran; etika yang harus dipakai dalam pembelajaran; etika peserta didik terhadap pendidik; etika terhadap pelajaran dan hal-hal yang harus dipedomani bersama pendidik; etika yang harus dipakai oleh pendidik terhadap dirinya; etika pendidik terhadap pelajaran; etika pendidik terhadap peserta didik; etika menggunakan media pendidikan dan hal-hal yang berkaitan dengannya. ${ }^{8}$

${ }^{6}$ Hasan Langgulung, Asas-asas Pendidikan Islam (Jakarta : Pustaka al-Husna, 1992), 359

7 KH. Hasyim Asy'ari, Adab al-'Alim wa al-Muta'allim , (Jombang: Maktabah al-Turats al-Islami, 1413 H), $12-13$

${ }^{8}$ Ibid., 109-110 
Dipilihnya judul dan pokok-pokok bahasan seperti yang telah disebutkan, merupakan hasil pertimbangan KH. Hasyim Asy'ari dengan terlebih dahulu mencermati dan melakukan istikharah.

Dalam kitab Adab al-'Alim wa al-Muta'allim bab I, KH. Hasyim Asy'ari menjelaskan tentang keutamaan ilmu dan ilmuwan serta pembelajaran. Dalam bab tersebut, $\mathrm{KH}$. Hasyim Asy'ari menyatakan akan banyaknya ayat-ayat Alquran dan Hadits yang menunjukkan keutamaan ilmu dan ilmuwan. Beliau banyak mengutip ayat-ayat dan hadits tentang hal tersebut, bahkan dikutip pula pendapat dari para ulama.

KH. Hasyim Asy'ari juga menyebutkan bahwa tujuan utama ilmu pengetahuan sesungguhnya adalah mengamalkan ilmu dalam tingkatan praksis kehidupan, dengan cara memanifestasikan dalam bentuk perbuatan nyata. Dalam bahasa lain ilmu yang amaliah dan amal yang ilmiah. Hal tersebut akan menghasilkan buah dan memberi manfaat sebagai bekal kehidupan di akhirat kelak. Mengingat begitu pentingnya hal tersebut, maka syari'at mewajibkan untuk menuntutnya dengan balasan pahala yang menyenangkan bagi penuntunnya.

KH. Hasyim Asy'ari memberikan pandangan bahwa, dalam proses pembelajaran seyogyanya diperhatikan dua hal :pertama, seorang peserta didik yang menuntut ilmu hendaknya berniat murni untuk menuntut ilmu dengan niat suci dan luhur, jangan sampai memiliki niat untuk memperoleh kepentingan yang berorientasi padaa duniawi. Kedua, seorang pendidik atau ulama dalam mengajarkan ilmunya, hendaknya meluruskan niatnya dulu, tidak mengharapkan materi semata-mata. Dan semua yang diajarkan hendaknya sesuai dengan tindakan dan perilaku yang diperbuat, dalam arti bukan sekedar hanya bisa menyampaikan belaka. ${ }^{9}$

KH. Hasyim Asy'ari sendiri, secara eksplisit tidak memberikan pengertian definitif tentang arti pembelajaran. Namun hubungan pendidik-peserta didik yang dimaksudkan oleh KH. Hasyim Asy'ari terkandung maksud adanya interaksi pendidikpeserta didik yang di dalam dunia pendidikan dikenal sebagai interaksi edukatif. Interaksi edukatif itu terjalin dengan adanya ikatan tujuan dan terjadi dalam lingkungan pendidikan. Dan pola interaksi yang terjadi di dalamnya merupakan interaksi edukatif.

Di dalam bab I KH. Hasyim Asy'ari juga menjelasan tentang eksistensi dan keberadaan seorang ilmuwan dibanding dengan orang biasa, beliau memberikan perumpamaan (tamtsil) bagaikan bulan dengan bintang. Barang siapa yang berusaha mencari ilmu, niscaya ia akan ditinggikan derajatnya. Beberapa keutamaan yang telah disebutkan tersebut merupakan sesuatu yang niscaya bagi seorang ilmuwan yang senantiasa mengamalkan ilmu dengan berbuat kebaikan, taqwa, dan memiliki tujuan untuk mendapatkan ridla dari Allah SWT, serta mencapai kebahagiaan disisi-Nya. ${ }^{10}$

Mengakhiri karya kitab Adab al-'Alim wa al-Muta'allim, KH. Hasyim Asy'ari menutup dengan tahmid (pujian) kepada Allah SWT, dan bacaan salam yang dipersembahkan kepada Sayyid al-Mursalin Nabi Muhammad SAW.

${ }^{9}$ Ibid., 12-13

10 Ibid., $12-24$ 
Kitab yang diberi nama Adab al-'Alim wa al-Muta'allim tersebut selesai disusun oleh KH. Hasyim Asy'ari pada hari Ahad tanggal 22 Jumad al-Tsani 1343 H. dan tidak tertulis secara pasti kapan tanggal, bulan dan tahun miladiyah-nya.

Pada bagian akhir kitab tersebut, tertera beberapa tanggapan dan respons dari kawan dan kolega KH. Hasyim Asy'ari yang merupakan tokoh-tokoh dari Negara Timur Tengah yang cukup apresiasif terhadap karya tersebut. Tokoh-tokoh itu antara lain : Sa'id ibn Muhammad al-Yamani (ulama' Masjid al-Haram), Abd al-Hamid Hadidy (ulama' Masjid al-Haram) dan Hasan ibn Sa'id al-Yamany (pengajar di Masjid al-Haram). Semua tanggapan dan respons dari beberapa tersebut, memberikan apresiasi yang positif untuk karya KH. Hasyim Asy'ari, Adab al-'Alim wa al-Muta'allim.

\section{Etika Peserta didik}

a. Etika dalam Belajar

Dalam bab II KH. Hasyim Asy'ari menetapkan beberapa hal tentang etika yang perlu diperhatikan oleh peserta didik sebagai penuntut ilmu agar ilmu yang diperolehnya bermanfaat. Menurutnya, ada sepuluh etika yang perlu diperhatikan, yaitu :

1) Membersihkan hati dari segala jenis tipuan, ucapan kotor, niat jahat, dengki, buruk aqidah dan buruk akhlak,

2) Memperbaiki niatnya di dalam menuntut ilmu. Maksudnya menuntut ilmu harus diorientasikan pada tujuan akhiratnya karena Allah semata, menghidupkan syari'at (ajaran Islam), menyinarkan hati, memperhias bathin dan mendekatkan diri kepada Allah. Tidak ada tendensi sedikitpun duniawi dalam hatinya, seperti bertujuan menjadi pemimpin, mencari pangkat dan kedudukan, harta, menyaingi teman dan lain-lain,

3) Peserta didik dimasa muda segera menghasilkan ilmu. Peserta didik dimasa ini dilarang terbujuk oleh rayuan, hayalan yang mengakibatkan menunda-nunda dalam menghasilkan ilmu pengetahuan. Hal demikian, karena seluruh waktu akan terlewati dan tidak akan kembali serta terganti oleh lainnya. Pada masa ini peserta didik disamping dituntut untuk meninggalkan hal-hal yang dapat mengganggu jalannya pencarian ilmu, peserta didik dituntut pula untuk mencurahkan segenap jerih payah dan kesungguhan demi menghasilkan ilmu,

4) Bersabar dan bersifat qana'ah terhadap segala macam pemberian maupun cobaan,

5) Pandai mengatur waktu malam dan siang harinya,

6) Mengurangi makan dan minum. Karena dengan perut kenyang dapat menimbulkan keengganan dan malas beribadah serta menyebabkan bertambah beratnya badan, sehingga malas untuk berbuat sesuatu termasuk dalam beribadah dan menuntut ilmu. Adapun manfaat mengurangi makan dan minum adalah menyehatkan badan dan mencegah timbulnya penyakit pada badan serta memberi waktu istirahat pada perut. Dari sini puasa merupakan solusi alternatif untuk menyehatkan badan disamping dapat meningkatkan aktifitas ibadah dan menuntut ilmu,

7) Melatih diri untuk selalu bersikap wara' (berhati-hati). Di samping itu peserta didik selalu berhati-hati dalam segala tindakannya, berusaha apa yang seharusnya dimakan dan diminum, pakaian yang dipakai serta tempat tinggal yang halal. Hal ini 
sangat penting dilakukan oleh peserta didik supaya selalu bersih dan bersinar hatinya, sehingga pada muaranya dapat memudahkan masuknya ilmu dalam relung jiwanya dan mengamalkannya,

8) Mengurangi makanan dan minuman yang menyebabkan kemalasan dan kebodohan (lamban berfikir), seperti minum cuka dan makanan yang dapat menyebabkan timbulnya lendir, seperti susu, keju, ikan dan lain-lain. KH. Hasyim Asy'ari juga menganjurkan untuk menjauhi hal-hal yang menimbulkan kelupaan, seperti memakan sesuatu dari bekas gigitan tikus, membaca papan di kuburan, berada diantara dua unta yang sedang berjejer dan membuang kutu kepala dalam keadaan masih hidup,

9) Meminimalisir waktu tidur sepanjang tidak merusak kesehatan. Bahkan KH. Hasyim Asy'ari menyarankan supaya tidur sehari semalam tidak melebihi dari delapan jam, yaitu sepertiga waktu. Selebihnya tentu digunakan untuk beribadah dan belajar, dan 10)Meninggalkan pergaulan yang kurang bermanfaat (lagha) terutama dengan lawan jenis. ${ }^{11}$

\section{b. Etika terhadap Pendidik}

Selanjutanya, KH. Hasyim Asy'ari dalam bab III membahas tentang etika seorang peserta didik terhadap pendidik. Beliau menyebutkan ada dua belas macam etika yang mesti dipegang.

Kedua belas macam etika itu meliputi :

1) Sepantasnya bagi peserta didik sebelum memulai belajar untuk berfikir dan beristikharah dalam menentukan siapa orang yang pantas dijadikan sebagai pendidiknya,

2) Memilih pendidik yang wara' dan professional atau mampu dibidangnya dan ia merupakan orang kepercayaan dari pendidik-pendidik lain yang hidup pada zamannya. Di samping itu hendaknya peserta didik mencari pendidik yang suka membahas berbagai masalah dan suka bergaul,

3) Mengikuti jejak-jejak "tindak lampani"pendidik dalam segala urusannya dan tidak boleh keluar dari pandangan dan aturannya, bahkan peserta didik diharapkan selalu menyertainya, ibarat orang sakit selalu mengikuti terhadap anjuran dokter yang mahir supaya lekas sembuh penyakitnya,

4) Hendaknya memandang bahwa pendidik itu sebagai orang yang patut dimuliakan dan menempatkannya pada tempat kesempurnaan. Dalam hal ini, peserta didik disarankan tidak memanggil dengan kata-kata "kamu", tetapi panggilan dengan kalimat yang manis, seperti ucapan "yaa sayyidina" atau "yaa ustadz"

5) Memperhatiakn hak-hak pendidik dan tidak melupakan kebaikan dan keutamaannya, mendo'akan selama hayat atau sesudah wafatnya, menjaga keturunan, kerabat, orang-orang yang dikasihi, menziarahi maqrabah, beristighfar, bersedaqah karenya, setia mengikuti perilaku baiknya, mengambil 
petunjuk di mana sang pendidik mengambilnya, dan menjaga kebiasaan di dalam agama dan ilmunya,

6) Bersabar terhadap sanksi yang diberikan pendidik,

7) Mengunjungi pendidik sesuai dengan tempat dan waktu yang telah disediakannya, atau meminta izin terlebih dahulu kalau keadaan memaksa tidak pada tempatnya,

8) Duduk yang rapi dan sopan ketika berhadapan dengan pendidik, seperti duduk bersimpuh atau duduk seperti orang yang sedang bertasyahud, hanya bedanya tidak usah meletakkan tangan di atas kedua paha atau duduk bersila dengan tawadlu' dan khusu' tanpa larak-lirik

9) Berbicara yang halus dan lembut,

10) Mendengarkan fatwa yang disampaikan oleh pendidik dengan seksama sambil mengambil faedahnya.

11) Jangan menyela-nyela pembicaraan pendidik tatkala ia sedang menjelaskan, dan

12) Menggunakan anggota yang kanan ketika menyerahkan sesuatu kepada pendidik. ${ }^{12}$

\section{c. Etika terhadap Pelajaran}

Dalam penjelasan tentang etika seorang peserta didik terhadap pelajaran dan halhal yang harus dipedomani peserta didik bersama pendidiknya, KH. Hasyim Asy'ari menuangkannya dalam bab IV, beliau menyebutkan ada tiga belas macam etika, yaitu :

1) Mengutamakan ilmu pengetahuan yang bersifat fardlu 'ain untuk dipelajari. Jenis ilmu fardlu 'ain ini ada empat macam, yaitu pertama, ilmu tentang Keesaan Allah (Tauhid). Pada ilmu ini cukup meyakini bahwa dzat yang Maha Luhur adalah wujud, bersifat abadi dan tak terbatas dari segala sifat kekurangan tetapi sebaliknya bersifat dengan segala kesempurnaan, kedua, ilmu tentang sifat. Dalam hal ini cukup meyakini bahwa dzat yang Maha Luhur disertai kuasa (qudrah), berkehendak (iradah), mengetahui (ilmu), hidup (hayat), mendengar (sama'), melihat (bashar), dan berbicara (kalam). Ketiga, ilmu fiqih, antara lain meliputi ilmu tentang tata cara bersuci (thaharah), shalat dan puasa serta hal-hal lain yang berhubungan dengan mu'amalah. Ilmu inilah yang berfungsi untuk mengetahui hukum-hukum Allah yang telah disyari'atkan. Keempat, ilmu tentang perilaku manusia (ilmu akhlaq/tasawuf).

2) Mempelajari ilmu pengetahuan yang menjadi pendukungnya, seperti hadits dan ilmu hadits, ushuluddin dan usul fiqh, serta ilmu nahwu dan sharof,

3) Berhati-hati dalam menanggapi ikhtilaf (perbedaan) para ulama' dan antara manusia secara mutlak tentang masalah aqliyyah dan sam'iyyah, karena bisa membawa kepada kebingungan hati dan akal. Tetapi dalam hal ini, KH. Hasyim Asy'ari menganjurkan pada awal belajarnya untuk berpegang pada satu kitab dalam satu cabang ilmu atau beberapa kitab untuk beberapa cabang ilmu,

4) Hendaknya peserta didik mentashih secara baik apa yang telah dibacanya sebelum dihafal, baik ditashih oleh pendidik atau yang lainnya yang sekira dapat 
mengukuhkannya. Setelah pelajaran dihafal sebelum ada pentashihan, karena dikhawatirkan mengalami perubahan yang akhirnya salah persepsi,

5) Menganalisa dan menyimak ilmu secara cermat,

6) Jika peserta didik menerangkan ringkasan hafalannya dan memberi kode hal-hal yang musykil dan faedah-faedah yang penting, hendaknya membahas melalui kitabkitab yang penjelasannya detail disamping harus terus muthola'ah mereferensikan apa yang ia pelajari atau dengan mendengarkan faedah-faedah yang indah, cabangcabang masalah yang masih asing dan membedakan antara hukum-hukum yang mutasyabihat dari yang lainnya. Karena begitu banyak persoalan yang dihadapi oleh peserta didik dalam situasi belajar, maka KH. Hasyim Asy'ari menyarankan pada peserta didik untuk selalu bercita-cita tinggi melalui eksplorasi dan pendalaman ilmu yang telah diwariskan para Nabi melalui para ulama secara kontinyu tanpa mengenal batas waktu dan tempat,

7) Menetapi lingkaran pengajaran, diharapkan sang pendidik memberikan kebaikan pada peserta didiknya. Sebab tidak ada yang namanya pendidik pada lingkup pendidikan itu menyesatkan manusia,

8) Mengucapkan salam ketika sampai di majlis ta'lim dengan suara yang sekira dapat didengar oleh yang ada dimajlis tersebut secara meyakinkan dan mengkhususkannya untuk sang pendidik sambil memberi penghormatan selayaknya, juga menyampaikan salam ketika hendak pergi dari majlis pendidik tersebut,

9) Bertanya jika terdapat persoalan yang belum dipahami dan berusaha memahami halhal yang belum sempurna,

10)Tidak mendahului teman-teman yang memiliki kepentingan untuk bertanya lebih dulu, kecuali minta izin sebelumnya,

11)Tidak lupa membawa catatan ketika hendak pergi kemana saja,

12)Mempelajari setiap pelajaran yang telah dipelajari sebelumnya (muthala'ah) secara terus menerus dan istiqamah, dan

13)Memiliki jiwa semangat belajar yang tinggi (ghirah) dengan sikap antusiame. ${ }^{13}$

\section{Etika Pendidik}

a. Etika Pendidik terhadap Dirinya

Bagi seorang pendidik, agar diberi kemudahan dan keberkahan dalam mengajar, hendaknya memperhatikan dua puluh macam etika yang dituangkan oleh KH. Hasyim Asy'ari dalam bab V. Dua puluh etika itu meliputi :

1. Senantiasa mutoqobah (merasa dekat dan terawasi) oleh Allah, baik ketika dilihat orang maupun dalam kesendirian,

2. Takwa kepada Allah dalam setiap gerak dan diamnya, ucapan dan perbuatan, karena pendidik adalah bapak rohani yang mengemban atas peserta didik yang dititipkan kepadanya untuk menjadi orang yang berguna bagi agama, nusa dan bangsa.

3. Memiliki sikap tenang,

4. Bersikap hati-hati (wara'), 
5. Rendah diri (tawadlu'),

6. Khusyu' kepada Allah,

7. Senantiasa mengadukan setiap persoalan kepada Allah,

8. Tidak memanfaatkan ilmu semata-mata untuk meraih dunia/materi,

9. Tidak memanjakan peserta didik,

10. Melakukan zuhud (menahan hawa nafsu) dalam hidupnya,

11. Menghindari setiap perbuatan yang dapat merendahkan diri,

12. Menghindari tempat-tempat maksiat,

13. Menyebarkan dan menyemarakkan syiar-syiar Islam serta berpegang teguh pada syari'at Islam,

14. Senantiasa mengamalkan sunnah-sunnah Nabi serta menghidupkan aktivitas keagamaan yang didalamnya mengandung tentang kemaslahatan umat melaui cara yang baik berdasarkan syara', adat, dan watak,

15. Istiqamah atas hal-hal yang disunnahkan oleh syara', baik fi'liyah maupun qauliyah, seperti membiasakan diri dengan membaca Alquran, dzikir kepada Allah dengan hati dan lisan secara ikhlas,

16. Bersikap ramah, ceria dan menebarkan salam kedamaian,

17. Membersihkan diri dari perbuatan-perbuatan yang dibenci oleh Allah,

18. Menumbuhkan semangat untuk menambah ilmu pengetahuan,

19. Tidak menganggap remeh atau mencegah untuk berusaha mengambil faedah yang belum ia ketahui dari orang yang menurut pangkat, nasab atau umurnya lebih rendah dari seorang pendidik, dan

20. Membiasakan diri untuk menulis, mengarang, dan meringkas. ${ }^{14}$

A. Etika Pendidik dalam pembelajaran

Pada bab VI, KH. Hasyim Asy'ari menjelaskan tentang etika pendidik ketika proses pembelajaran berlangsung. Menurutnya, ada dua puluh etika, yaitu :

1. Mensucikan diri dari hadats, baik hadats kecil maupun besar,

2. Berpakaian rapi dan berbau wangi,

3. Niat ibadah dalam mengajarkan ilmu,

4. Menyampaikan hal-hal yang diajarkan oleh Allah,

5. Membiasakan membaca dalam rangka menambah ilmu pengetahuan,

6. Mengucapkan salam ketika akan masuk ke kelas,

7. Berdoa ketika akan mengajar, doa untuk segenap para ahli ilmu yang telah meninggal,

8. Berpenampilan kalem dan menjahui sesuatu yang tidak pantas dilihat mata,

9. Tidak banyak berguarau dan tertawa,

10. Tidak mengajar ketika badan dalam kondisi lapar, marah, dan lesu mata,

11. Duduk ditempat yang strategis ketika mengajar,

12. Berpenampilan ramah, lemah lembut, tegas dan lugas,

13. Memulai pelajaran dari hal-hal yang penting, yang disesuaikan dengan kompetensi dan keahlian yang dimiliki, 
14. Tidak mengajarkan hal-hal yang masih diragukan kejelasannya (syubhat),

15. Memperhatikan kemampuan masing-masing peserta didik dalam penyerapannya terhadap materi dengan waktu yang tidak terlalu lama,

16. Menciptakan ketenangan ruangan belajar,

17. Memberikan nasehat dan teguran dengan baik terhadap peserta didik yang suka malas,

18. Bersikap terbuka terhadap persoalan-persoalan yang dijumpai,

19. Memberi kesempatan terhadap peserta didik yang datang terlambat dengan cara mengulangi penjelasan supaya dia memahami pelajaran, dan

20. Ketika pelajaran sudah selesai dibahas, berilah kesempatan kepada peserta didik untuk menanyakan persoalan yang belum dimengerti. ${ }^{15}$

\section{Etika Pendidik terhadap Peserta didik}

Dalam pembahasannya yang diulas pada bab VII. KH. Hasyim Asy'ari menjelaskan tentang etika seorang terhadap para peserta didiknya. Menurut KH. Hasyim Asy'ari ada empat belas etika yang harus dicamkan, yaitu :

1. Berniat mendidik dan menyebarkan ilmu pengetahuan serta menghidupkan syari'at Islam,

2. Menghindari pamrih atau berorientasi pada hal-hal duniawi,

3. Senantiasa melakukan introspeksi diri,

4. Menggunakan metode yang sekiranya gampang dipahami oleh peserta didiknya,

5. Menumbuhkan antusiasme yang tinggi terhadap peserta didik dengan cara selalu memberi motivasi,

6. Memberikan latihan-latihan yang dapat menopang kompetensi peserta didik,

7. Senantiasa memperhatikan kemampuan peserta didik,

8. Tidak pilih kasih, yakni terlalu memperhatikan salah satu peserta didik dengan mengabaikan peserta didik yang lain,

9. Senantiasa mengarahkan bakat dan minat peserta didik,

10. Bersikap terbuka dan lapang dada terhadap peserta didik,

11. Membantu memecahkan kesulitan yang dihadapi oleh peserta didik,

12. Ketika terdapat peserta didik yang absent masuk, hendaknya seorang pendidik menanyakan hal ihwalnya kepada teman yang lain,

13. Menujukkan sikap arif dan kasih sayang kepada peserta didik, dan

14. Bersikap tawadlu' (rendah hati). ${ }^{16}$

4. Etika Pendidik dan Peserta didik terhadap Media Pembelajaran

Sebagai seorang pendidik atau peserta didik yang tugasnya sebagai subyek dari ilmu pengetahuan, maka perlu memperhatikan etika-etika yang dipaparkan oleh $\mathrm{KH}$. Hasyim Asy'ari dalam bab VIII, etika tersebut meliputi :

1. Menganjurkan dan mengusahakan agar memiliki buku pelajaran yang diajarkan,

15Ibid., 71-80

16Ibid., 80-95 
2. Mengizinkan bila ada teman yang butuh pinjaman buku pelajaran, sebaiknya sang peminjam harus senantiasa menjaganya,

3. Meletakkan buku pelajaran/kitab pada tempat yang layak dengan maksud menghormati pelajaran,

4. Memelihara kitab/buku pelajaran dengan baik dan benar,

5. Suci dari hadats kecil dan besar, kotoran, menghadap kiblat, dan memulainya dengan bacaan basmalah serta mengakirinya dengan bacaan hamdalah diikuti dengan shalawat dan salam pada para Nabi. ${ }^{17}$

\section{Refleksi: Memahami Etika Pendidik dan Peserta Didik}

Sebagai upaya untuk memahami beberapa premis di atas, KH. Hasyim Asy'ari sesungguhnya berusaha mengedepankan pemikiran bahwa dalam menghadapi segala persoalan, hendaknya dimulai dari paradigma normatif yang bersumbu pada titik sentral ketuhanan. Paradigma ini diasumsikan akan mampu menyelesaikan pelbagai problematika secara tuntas sehingga tidak menimbulkan spekulasi yang berkepanjangan. Dimensi ketuhanan hendaknya mampu menjelma pada partikulasi-partikulasi, terutama dalam perilaku sosial, sehingga secara keseluruhan menunjukkan satu bingkaian yang utuh. Tampaknya, KH. Hasyim Asy'ari berkeyakinan bahwa orang yang mampu menunjukkan integritas dalam berperilaku adalah makhluk Tuhan yang terbaik.

Pemikiran KH. Hasyim Asy'ari ini tampaknya menyiratkan sebuah pengertian bahwa yang menjadi sentral pendidikan adalah hati. Penekanan pada hati ini, dengan sendirinya dapat membedakan diri dari corak pemikiran pendidikan yang berliran progresivisme dan esensialisme. Aliran progresivisme-yangdipelopori oleh John Dewey-menyatakanbahwa sentral pendidikan adalah pikiran dan kecerdasan. Pikiran dan kecerdasan ini merupakan motor penggerak dan penentu ke arah kemajuan sekaligus penuntun bagi subyek untuk mampu menghayati dan menjalankan sebuah program. ${ }^{18}$ Dengan demikian, aliran progresivisme menitik beratkan pada aspek kecerdasan. Sedangkan aliran esensialisme menyatakan bahwa materi utamalah yang menentukan dan memantapkan pikiran serta kecerdasan manusia. Materi (bahan pengajaran) itulah yang sekaligus menjadi unsur-unsur yang haqiqi dalam sebuah perkembangan peradaban dan kebudayaan. Atas dasar klasifikasi tersebut, menjadi semakin jelas, bahwa $\mathrm{KH}$. Hasyim Asy'ari menempatkan corak-corak pemikiran pendidikan yang lain, yakni tidaklah bercorak progresif ataupun esensialis.

Perbedaan-perbedaan ini dimungkinkan oleh karena adanya titik pandang yang tidak sama dalam memahami manusia. Baik aliran progresif maupun esensialis samasama mendasarkan pandangannya pada penelitian-penelitian yang bersifat empirik. Sedangkan KH. Hasyim Asy'ari-yang identik dengan pemikiran al-Ghazalimenyimpulkan bahwa substansi manusia bukan terletak pada unsur fisiknya, melainkan pada hatinya. Sebagai pandangan pendidikan yang didasarkan atas hati, memang dengan sendirinya akan menghadapi kesulitan tersendiri, terutama ketika dikontekskan dalam

17Ibid., 95-99

${ }^{18}$ Imam Barnadib, Filsafat Pendidikan suatu Tinjauan (Yokyakarta: Andi Offset, 1987), 25 
usaha verifikasi dan pembuktian ilmiah. Sebab, usaha verifikasi dan pembuktian ilmiah membutuhkan kerangka empiris sehingga agak sulit untuk mencari titik temunya.

Kecenderungan para filosof Barat dalam memandang manusia lebih banyak dari sisi antroposentris, sedangkan filosof Islam seperti al-Ghazali, memandangnya dari sisi teosentris. Dengan demikian, dalam pendidikan Islam, tugas pendidik tidak hanya mencerdaskan pikiran sebagaimana yang dianut oleh aliran progresivisme, atau menyiapkan bahan-bahan yang baik sebagaimana dianut oleh aliran esensialisme, melainkan juga bagaimana membimbing, mengarahkan, dan menuntun hati agar dekat kepada Allah SWT. Sebab ilmu pengetahuan pada hakekatnya dipandang sebagai upaya mengembalikan jati diri manusia ke dalam fitrahnya. Bekerjanya akal, hati dan alat-alat pengetahuan tentu masih dalam pengertian fitrah yang sampai pada hakekat. ${ }^{19}$ Selaras dengan konsep tersebut, UU Sisdiknas tahun 2003 dalam bab II pasal 3 menyebutkan "Pendidikan Nasional berfungsi mengembangkan kemampuan dan membentuk watak serta peradaban bangsa yang bermartabat dalam rangka mencerdaskan kehidupan bangsa, bertujuan untuk berkembangnya potensi peserta didik agar menjadi manusia yang beriman dan bertakwa kepada Tuhan Yang Maha Esa, berakhlak mulia, sehat, berilmu, cakap, kreatif, mandiri, dan menjadi warga Negara yang demokratis serta bertanggung jawab". ${ }^{20}$

Sesungguhnya, pendidikan dalam konteks apapun tetap tidak bisa dilepaskan dari dimensi ilahiyyat. Asumsi ini dikuatkan oleh pendapat David Fracy yang menegaskan "bahwa ilmu pengetahuan itu sendiri mengandung dimensi religius. Karena tidak dapat memahami dan menerima dasar rasional argumentasinya manusia membutuhkan sesuatu yang Trancendensi Kognitif. ${ }^{21}$

Kendati demikian, dalam kenyataan praktek di lapangan banyak dijumpai, bahwa tugas pendidikan lebih banyak difokuskan pada aspek yang terakhir itu, yakni bagaimana membentuk orang-orang yang shaleh dalam perspektif Tuhan, tentunya Tuhan dalam sesuatu yang dipahaminya. Sementara aspek yang lain, yang tidak kalah pentingnya, yakni penguatan kecerdasan dan penguasaan materi pelajaran, menjadi terabaikan. Hal ini dimungkinkan oleh beberapa hal, diantaranya adalah cukup intensnya intervensi pemahaman keagamaan yang kurang memberi penghargaan terhadap aspek kecerdasan dalam aplikasi pendidikan. Kenyatan ini semakin mempermudah dalam menafikan dimensi-dimensi kependidikan yang kritis. Padahal meminjam perspektif yang dipakai oleh Abdul Munir Mulkan, bahwa pendidikan Islam penting untuk menumbuhkan daya kritis, kreatif, kecerdasan personal, sosial, dan kemanusiaan dengan fokus bukan semata kemampuan ritual dan keyakinan tauhid. ${ }^{22}$

Selanjutnya, KH. Hasyim Asy'ari menguraikan beberapa aspek lain, seperti materi ilmu pengetahuan. Persoalan ini dapat dipahami dari pandangannya tentang tujuan

\footnotetext{
${ }^{19}$ M. Bahri Ghazali, Konsep Ilmu menurut al-Ghazali (Jakarta: Pedoman Ilmu Jaya, 2001), 35

${ }^{20}$ Undang-undang Sistem Pendidikan Nasional No. 20 Tahun 2003,12

21 M. Bahri Ghazali, Konsep Ilmu menurut al-Ghazali, 33-34

${ }^{22}$ Abdul Munir Mulkan, Nalar Spritual Pendidikan (Yogyakarta: PT. Tiara Wacana, 2002), 66
} 
belajar, yaitu peserta didik hendaknya dalam menuntut ilmu itu semata-mata sepenuhnya ditujukan untuk mencapai ridla Allah, tidak untuk kepentingan dunia-materi. ${ }^{23}$

Tujuan seperti inilah, menurut Azyumardi Azra-dengan merujuk pada surat azDzariyat-merupakan tujuan pendidikan Islam. ${ }^{24}$ Dalam konteks ini, persoalanpersoalan epistemologi harus dikaitkan dengan etika dan nilai-nilai spritualitas. Artinya, materi pengetahuan yang dipelajari harus bertumpu pada konteks etika Islam dan nilainilai ketuhanan (Ilahiyyat). Sehingga ruang lingkup yang mesti dikaji oleh peserta didik meliputi dua hal, yaitu wilayah kajian ilmu keakhiratan dan ilmu keduniawian. Sementara KH. Hasyim Asy'ari sangat memprioritaskan pada aspek pertama, yaitu aspek wilayah kajian ilmu keIslaman dalam arti sempit. Hal tersebut sangat jelas tercermin dalam materi yang dikaji terlalu menampakkan materi-materi keislaman.

Berkaitan dengan hal itu, kiranya dapat disebutkan bahwa KH. Hasyim Asy'ari mengharuskan peserta didik untuk patuh dan tunduk pada anjuran dan perintah pendidiknya. Bahkan dikatakan, meskipun pendidik itu salah, maka itu harus diikuti. Sebab, kesalahan yang ada pada pendidik lebih baik dari pada kebenaran yang ada pada peserta didik. Selain itu, peserta didik tidak dibenarkan untuk mempunyai gagasangagasan yang tidak sejalan dengan pendidik. 25 Potret paling jelas dari dinamika pendidikan yang menerapkan pandangan dan budaya tersebut, bisa dilihat dari gambaran yang ada di sejumlah pesantren salafi di Indonesia, terutama di daerah Jawa. ${ }^{26}$

Di satu sisi, pandangan ini kurang mencerminkan memberikan peluang dan apresiasi kepada peserta didik untuk mengembangkan potensi intelektual dan kemampuan lainnya. Namun, di sisi yang lain, pandangan ini mencerminkan tingkat konsistensi pemikiran KH. Hasyim Asy'ari yang secara genuine mengagungkan ahli ilmu. Pendidik sebagai orang yang mempunyai kapasitas keilmuan patut diprioritaskan dari pada peserta didik.

Pemikiran KH. Hasyim Asy'ari yang tidak kalah pentingnya adalah legitimasi akal sebagai pemberian (mawahib) Tuhan yang sangat istimewa. Kebodohan merupakan musibah yang paling mengerikan. Bagi peserta didik, pandangan ini menjadi kebanggaan tersendiri sekaligus menjadi problem. Dikatakan sebagai kebanggaan, disebabkan oleh karena dengan sendirinya peserta didik, sebagai orang yang seringkali melibatkan akal, mampu melanggengkan sekaligus mengembangkan mawahib tersebut. Sedangkan dikatakan problem, karena dikhawatirkan peserta didik tidak mampu mengembangkan akal itu sehingga dirinya terjebak dalam kebodohan. Sebab, menggunakan akal berarti mencari pengetahuan dan pengertian yang jelas serta mengandung verifikasi bukti-bukti, sehingga perlawanan akal adalah suatu kebodohan. ${ }^{27}$

Pandangan di atas mengasumsikan bahwa peserta didik harus mampu mengembangkan daya intelektualitasnya guna menemukan-menemukan kebenarankebenaran yang ada dalam kajian apapun, termasuk keimanan ataupun ibadah. Oleh

${ }^{23}$ Hasyim asy'ari, Adab al-Alim wa al-Muta'allim, 22

${ }^{24}$ Azyumardi Azra, Pendidikan Islam, Tradisi dan Modernisasi Menuju Millenium Baru, 8

${ }^{25}$ KH. Hasyim asy'ari, Adab al-Alim wa al-Muta'allim, 29-30

${ }^{26}$ Karel A. Steenbrink, Pesantren Madrasah Sekolah,143

${ }^{27}$ Muzayyin Arifin, et al., Teori-teori Pendidikan Berdasarkan Al-Qur'an (Jakarta: Rineka Cipta, 1994), 
karena itu, KH. Hasyim Asy'ari telah memberikan petunjuk yang sangat jelas bagi peserta didik untuk tekun dan betul-betul giat dalam proses pencerdasan akal serta mengajukan waktu-waktu tertentu untuk pengembangan daya intelektualnya itu. Penempatan akal yang begitu besar dan didukung dengan petunjuk pengembangannya, ternyata telah menjadi bukti terhadap asumsi di atas, yakni bagi KH. Hasyim Asy'ari, posisi ilmu berada di atas iman dan sekaligus ibadah. ${ }^{28}$

Metode pembelajaran bagi peserta didik yang ditawarkan oleh KH. Hasyim Asy'ari adalah metode hafalan. Metode ini lebih diprioritaskan ketimbang dengan metode lain, seperti diskusi. Sebagaimana dikatakan oleh KH. Hasyim Asy'ari, bahwa hafalan adalah sangat penting dalam proses pembelajaran, sebab ilmu didapat bukan dari catatancatatan di buku, karena hal demikian mempunyai dampak yang kurang baik. Agaknya penekanan metode hafalan ini selain sebagai salah satu karakteristik tradisi syafi'iyyah, juga menjadi salah satu ciri umum dalam tradisi pendidikan Islam.

Jika ditelusuri lebih jauh, metode hafalan saat ini dikenal dalam teori psikologi asosiasi yang dikembangkan oleh J. Herbert yang pada prinsipnya beranggapan bahwa jiwa manusia terdiri dari kesan-kesan yang masuk melalui penginderaan. Metode pembelajaran dalam teori ini disebut dengan "formal step" yang mengatakan bahwa pembelajaran yang baik adalah dengan jalan memperbanyak hafalan dengan menggunakan hukum asosiasi reproduksi, dengan faktor ingatan yang sangat menonjol. ${ }^{29}$

Adapun metode pembelajaran yang lain, terdapat dalam psikologi behavioristik yang disebut "S-R Bond Theory". Metode ini menafsirkan pembelajaran sebagai latihanlatihan pembentukan hubungan antara stimulus dan respons. Hubungan stimulusrespons ini akan menimbulkan kebiasaan-kebiasaan otomatis pada belajar. ${ }^{30}$

Disamping itu, ada banyak metode pembelajaran yang dikenal pendidik. Namun bagaimanapun semua pendekatan pada hakekatnya harus dapat menunjang peserta didikbelajar aktif. Berbagai pendekatan dan metode yang mendorong peserta didik belajar aktif, yaitu: dengan pemberian tugas, demonstrasi, diskusi, karyawisata, latihan, sosiodrama, proyek, dan ceramah. ${ }^{31}$

\section{Kesimpulan}

Jika dilihat dari aspek kandungan dalam konsep pemikiran pendidikan KH. Hasyim Asy'ari, dapat disimpulkan bahwa peserta didik harus mampu mengaplikasikan pengetahuan dengan kesatuan amaliah (perbuatan) yang menjunjung tinggi nilai-nilai akhlak yang luhur secara integratif. Pemahaman ini ditemukan berdasarkan pada penekanannya yang sangat tajam dalam bidang etika peserta didik. Hal tersebut menyiratkan adanya sebuah hubungan yang sangat erat antara pengetahuan dan perbuatan. Pola integrasi antara pengetahuan dan perbuatan tersebut, saat ini dikenal dengan konsep pencapaian pembelajaran yang meliputi tiga domain, yaitu: kognitif, afektif, dan psikomotorik. Tiga domain tersebut merupakan taksonomi yang

${ }^{28}$ KH. Hasyim asy'ari, Adab al-Alim wa al-Muta'allim, 16

${ }^{29}$ Oemar Hamalik, Kurikulum dan Pembelajaran (Jakarta: Bumi Aksara, 1995), 42

30Ibid.,43

${ }^{31}$ H. Ramayulis, Ilmu Pendidikan Islam (Jakarta: Kalam Mulia, 2004), 170 
dikembangkan oleh Benyamin S. Bloom. Sistem pembelajaran di sekolah sekarang ini mengelompokkan tujuan pendidikan yang hendak dicapai ke dalam tiga domain tersebut (kognitif, afektif, dan psikomotorik). Sebagai tujuan yang hendak dicapai, tiga domain harus nampak dan dipandang sebagai hasil pembelajaran.

Hubungan integritas demikian adalah menjadi suatu hal yang niscaya. Sebab, tentu pengetahuan secara logis, harus diikuti dengan perbuatan yang baik. Ini tidak hanya disebabkan karena takwa kepada Allah yang didefinisikan dalam istilah-istilah perbuatan yang baik, secara individual maupun sosial, pribadi atau umum, tetapi karena perbuatan termasuk dalam lingkup istilah 'alim sendiri. Dengan demikian, peserta didik sebagai orang yang berusaha menjadi 'alim meniscayakan adanya pengintegrasian aspek pengetahuan dengan aspek perbuatan tersebut.

\section{Daftar Rujukan}

Ali, Hery Noer. Ilmu Pendidikan Islam. Jakarta: Logos Wacana Ilmu, 1999.

Al-Munawwar, Said Agil Huzain. Aktualisasi Nilai-Nilai Qur'ani Dalam Sistem Pendidikan Islam. Ciputat: PT. Ciputat Press, 2005.

Arifin, Muzayyin. Teori-teori Pendidikan Berdasarkan Al-Qur'an. Jakarta: Rineka Cipta, 1994.

Asy'ari, Hasyim. Adab al-'Alim wa al-Muta'allim. Jombang: Maktabah al-Turats al-Islami, $1413 \mathrm{H}$.

Azra, Azyumardi. Pendidikan Islam, Tradisi dan Modernisasi Menuju Millenium Baru. Jakarta: Logos Wacana Ilmu, 2000.

Barnadib, Imam. Filsafat Pendidikan suatu Tinjauan. Yokyakarta: Andi Offset, 1987.

Ghazali, M. Bahri. Konsep Ilmu menurut al-Ghazali. Jakarta: Pedoman Ilmu Jaya, 2001.

Hamalik, Oemar. Kurikulum dan Pembelajaran (Jakarta: Bumi Aksara, 1995)

Khuluq, Lathiful. Fajar Kebangunan Ulama. Yogyakarta: LkiS, 2000.

Kuntowijoyo, Paradigma Islam, Interpretasi untuk Aksi. Bandung: Mizan, 1991.

Langgulung, Hasan. Asas-asas Pendidikan Islam. Jakarta : Pustaka al-Husna, 1992.

Mas'ud, Abdurrahman. Dari Haramain ke Nusantara. Jakarta: Kencana, 2006.

Masyhuri, A. Aziz. 99 Kiai Pondok Pesantren Nusantara. Yogyakarta: Kutub, 2006.

Mulkan, Abdul Munir. Nalar Spritual Pendidikan. Yogyakarta: PT. Tiara Wacana, 2002.

Nata, Abuddin. Filsafat Pendidikan Islam. Jakarta: Logos Wacana Ilmu, 2001.

Priatna, Tedi. Reaktualisasi Pendidikan Islam. Bandung: Pustaka Bani Quraisy, 2004.

Ramayulis, H. Ilmu Pendidikan Islam. Jakarta: Kalam Mulia, 2004.

Undang-undang Sistem Pendidikan Nasional No. 20 Tahun 2003 